\title{
Hydrocarbon Concentration Levels in Groundwater in Jesse and Environ, Ethiope West L.G.A. Delta State, Nigeria
}

\author{
Ibezue Victoria C (Ph.D) \\ Department of Geology, \\ Faculty of Physical \\ Sciences, COO University, \\ P.M.B. 02, Uli, Nigeria
}

\author{
Odesa Erhiga G. \\ Department of Geology, \\ Faculty of Physical Sciences, \\ COO University, P.M.B. 02, \\ Uli, Nigeria
}

\author{
Ndukwe John O \\ Department of URP, Faculty \\ of Envtl Sciences, \\ COO, University, \\ P.M.B. 02, Uli, Nigeria
}

\author{
Nwabineli Emma, O (Ph.D) \\ Department of Ceramics and \\ Glass, \\ Akanu Ibiam Federal \\ Polytechic Unwana, \\ Ebonyi, State, Nigeria.
}

\begin{abstract}
This study investigated Total petroleum hydrocarbon (TPH) content of groundwater samples from Jesse and environs, Delta State Nigeria to ascertain the level of concentration of polycyclic aromatic hydrocarbon and the Aliphatic components in the water sample from the study area.10 groundwater samples were collected from ten (10) different water borehole in Urhodo, Okurodo, Ajanasa, Idjedaka. etc in Jesse. The samples collected were analyzed using Gas chromatography method (GC-MS method). The result shows that the polycyclic aromatic hydrocarbon content ranges from 0.002 to $0.007(\mathrm{mg} / \mathrm{l})$ and the aliphatic hydrocarbon content ranges from 0.03 to $0.422 \mathrm{mg} / \mathrm{l}$. This concentrations levels when compared with standard limits from World Health Organization (WHO) tables, indicates that the concentrations of the Total petroleum hydrocarbon is relatively low and within the permissible limit. Thus, the contamination of the environment by total petroleum hydrocarbon in the study area pose no harmful threat to the environment. However, Periodic monitoring will serve for the protection of the groundwater supply in the study area. Further oil spillage should be avoided as it may lead to accumulations of hydrocarbons at dangerous level.
\end{abstract}

Keywords: hydrocarbons, groundwater, concentration, environment, contamination, oil spillage 


\section{Introduction}

Groundwater contamination resulting from hydrocarbon spill is a major problem in Nigeria. Environmental resource activities; such as industrialization, mining, crude exploitation, that damage water supplies has serious consequences on the ecosystem, this has led to the recognition of its importance, however despite its importance, regulation to prevent and preserve the environment are relatively unsatisfactory in preventing spill to the groundwater. Crude oil is the main source of revenue to the federal government, it contribute over $70 \%$ to the foreign earnings of the government [2], and of hydrocarbon, it is made up of a complex mixture of hydrocarbon with different structures and molecular weight, which vary from the highly volatile substance to complex waxes and asphalt components [1].

Hydrocarbons pollution generally pose serious risk to the environment, however, its contribution to the economy and delayed manifestation of effect of oil exploration and exploitation make it difficult to fully appreciate their contribution to the disease burden in Nigeria, especially in the oil-producing communities. The emergence of non-communicable diseases like dermatitis, respiratory difficulties, anaphylactic shock kidney damages, neurological conditions, carcinogenic effects etc [17], among Nigerians has sent a warming message across to stakeholders. Each year, number of Post-Impact Assessment (PIA) studies is conducted to assess the impact of the hazards generated by the oil industry on the physical and social environment and on public health [6], [7]. Most of these studies are conducted without any significant contributions from health professionals and are reported without highlighting the immediate and long-term implications of the identified hazards on the health of members of the impacted communities [15]

Generally, spills and leaks to groundwater, regardless of their sizes, they are potentially dangerous. Hydrocarbons can bio-accumulate in food chains where they disrupt biochemical or physiological activities in many organisms, thus causing carcinogenesis in some organs, mutagenesis in the genetic material, impairment in reproductive capacity and / or causing hemorrhage in exposed population [15]. Different authors present different definition for pollution common view is that pollution is introduction into the physical environment of substances that are capable of interfering with human health condition, the quality of life, or the natural functioning of the ecosystem (living organisms and their physical surroundings).

Hydrocarbon spillage and fire outbreak in Jesse community, Delta state, drew the attention of researchers to the long standing spillage in Jesse community and its environment. Researchers dig deep into the environmental impact assessment of the repeated spillage on this area. Little is known about the hydrocarbon contamination to the groundwater 
in Jesse community and its environment where hydrocarbon spillage has occurred several times. One point is clear that contamination and possible pollution of groundwater by oil spill is significant, dangerous and real in Jesse community and environ.

For water to be adequately utilized, it has to be reasonably free from contaminants. Otherwise, such waters could pose serious health and environmental risks to living organisms that depend on them [5]. The widespread use of petroleum products as fuels, lubricants and solvents has led to high incidence of groundwater contamination by hydrocarbons. Despite the long standing recognition of the pollution threat from petroleum hydrocarbons little has been known about groundwater contamination by these products, as researchers tend to concentrate on the surface environment such as hydrocarbon spillage on surface water and soil.

The objective of the study is to assess and ascertain the level of hydrocarbon concentration in the groundwater of the study area owing to incessant oil spillage. In order to do this, the following steps became necessary; they include:

- To determine the concentrations of hydrocarbon contaminants in groundwater in Jesse town and environs as a result of oil and gas exploration and exploitation activities in the area.
- Evaluate the area extent of the hydrocarbon contamination in groundwater in the study area.

- To assess if the groundwater in Jesse and the environment consistently meet the WHO guidelines for different uses.

Ground elevation in Jesse and environ is generally less than 50 meters above mean sea level and there is a marked absence of imposing hills that rise above the general land scape. The climate is of humid sub-equatorial with a long wet season lasting from March to October that alternates with a short dry season that lasts from November to February. Annual temperature average in Jesse is about $27^{\circ} \mathrm{C}$ [17].

The study is limited to the confines of assessing and appraising the concentrations of hydrocarbon contaminants on groundwater in the study area as a result of repeated oil spill in Jesse communities and environs in Ethiope West Local Government Area, in Delta State Nigeria. The study evaluate the impact of hydrocarbon contaminant on the groundwater of Jesse communities and environs using water sample from ' 10 ' different sources of groundwater (bore-holes and hand-dug wells) from the study area .The sample was analyzed for Total Petroleum hydrocarbon (TPH), and PAH using the Gas Chromatography system 6890 series. 


\section{Relevance of the Investigation}

This work is relevant to students with interest in water resources and the environment. Water resources and landuse planning experts will borrow a leaf from this study as it provides with vital information on the extent to which human activities can influence the groundwater quality even in the subsurface. Governments and policy makers and in fact all stakeholders in environmental protection and sustainable development will be better advised by consulting this research work. Above all, public health are better secured with adequate and updated information from researches such as this.

\section{Brief Review of Literature}

Jesse communities and its environment have been exposed to oil related activities like gas flaring and oil spillage. Gas flares release contaminated fumes into the atmosphere while oil spillage leak oils into the environment either through accidental discharges, sabotage and the likes. When the contaminants get into water bodies, they interfere with the water quality and these could trigger health and environmental effects [3]. However, there have been several approaches developed for the safety and management of environmental impact of oil and natural gas exploration and production operations in the Nigeria. Over the past years, the Nigerian Government has promulgated laws and regulations so that oil and gas exploration and production operations, on both onshore and offshore oilfields, could be controlled by systems of limits which aim at minimizing the associated environmental impacts.

Some of the related environmental laws and regulations in the oil and gas sector include:

\author{
*Mineral Oils (safety) Regulations (1963); \\ * $\quad$ Oil in Navigable Waters Acts (1968); \\ * Petroleum Acts (1969); \\ * the Federal Environmental Protection \\ Agency (FEPA) Act (1988); \\ * the National Policy on the Environment, \\ (1989); (revised in 1999);
}

* National Environmental Protection (Effluent Limitations), Regulations (1991); Environmental Protection (Pollution Abatement in Industries Generating Wastes) Regulations (1991) and

* $\quad$ Environmental Impact Assessment (EIA) Act (1992), and Department of Petroleum Resources (DPR) Environmental Guidelines and Standard for the Petroleum Industry in Nigeria (EGASPIN 2002). 
The Nigerian situation can be viewed thus: statutory laws and regulations that were intended to provide the framework for Petroleum Resources Exploration and Exploitation did not address issues of petroleum pollution except for a few environmental regulations. Implementation of the laws and regulations are not in view, in spite of the number of existing structures that should have manned that forth of ensuring compliance with rules of operation. Despite all the regulations, groundwater contamination due to petroleum activities is unattended.

Groundwater samples taken from Luiwi in Ogoni land (where oil exploration and exploitation activities have been on till production stopped in 1993) were analyzed in the United State. It was discovered that the sample contained $18 \mathrm{ppm}$ of hydrocarbons. This amounts to 360 times the level allowed in drinking water in European Union (E.U) while another sample from Ikwere in Rivers state, Nigeria contained 34ppm and about 680 times the EU standard for drinking water.

The Formation Strata and Groundwater Potential in Sapele Metropolis (which include Jesse and Oghara) was determined by correlating results of seismic refraction survey and those of electrical resistivity studies and discovered that the numbers of layers delineated differ. But the viable aquifer at Sapele and Jesse are generally within $25 \mathrm{~m}$ below the surface although false and contaminated aquifer may be intercepted at $10-15 \mathrm{~m}$.
On the contrary, Oghara is more of sandy formation with aquifer over 35 $m$ thick [14].

The ground waters in Warri and Abraka and the effects of gas flaring on rain and surface water in Okpai and Beneku respectively in Delta State was examined and the result established that while ground waters were relatively safe in both cases the rain and surface waters needed treatment before it could be consumed [12]

The formation strata and groundwater potential in Sapele metropolis, Jesse and Oghara was determined by correlating results of seismic refraction survey and those of electrical resistivity studies [14]. The submission was that the numbers of layers delineated differ, but the viable aquifer at Sapele and Jesse is generally within $25 \mathrm{~m}$ below the surface although false and contaminated aquifer may be intercepted at $10-15 \mathrm{~m}$. On the contrary, Oghara is more of sandy formation with aquifer above 35 m thick.

Generally, when petroleum comes in water a very fast partitioning between the water, air and sediment part of the environment take place [9]. The insoluble fraction forms a layer of 0.01 to $3.0 \mathrm{~mm}$ thickness on the water layer [10]. During the first few hours some parts evaporate and other parts are absorbed in the sediment. When the hydrocarbons are concentrated enough non-aqueous phase liquids (NAPLs) can be formed. The remaining hydrocarbons are present in the aqueous layer or as a film on the water surface. The lighter fractions are removed within twenty- 
four hours by evaporation [[13]. However, the evaporation of alkanes is possible until an 18 carbon chain [9]. The mass loss due to evaporation can range for $0.1 \%$ for heavier oils to $17.3 \%$ for lighter oils [8].

\section{Methodology}

The study adopted the experimental research design and used random sampling to select the bore-hole used in the study. Water sample were collected from the selected bore-hole, thereafter the samples were taken to Splendid Stan Research laboratory limited Benin City Nigeria who did the extraction analysis. The method adopted for the sample collection and preparation was in line with America Petroleum Institute (API). Quality assurance /quality control form an integral part of the sample collection processes

By measuring 100 millilitre $(100 \pm 0.0 \mathrm{ml})$ of water sample, and $100 \mathrm{ml}$ of dichloromethane (DCM) via separating funnel and shacked for $30 \mathrm{~min}$ for BPA extraction. The separating funnel was clamp and the mixture was allowed to separate out. After separation the DCM portion was collected. The process was repeated three times for complete extraction and Gas chromatography analysis was done using Flame Ionization Detection methods. The conditions used were designed to measure the levels of C9 to C36 range of hydrocarbons: An appropriate column and temperature program, which separate the solvent peak from $\mathrm{C} 9$ and was able to elute the last component, $\mathrm{C} 36$, in a reasonable time period (about 30 minutes) was used. Detection was achieved by FID. The analytical result thereafter was computed using statistical model and compared with WHO standard in other to determine the significance of the hydrocarbon in the study area.

\section{Findings}

The result of the chemical analysis of the groundwater sample obtained from Jesse and environs is presented in the tables below 
Table1: Total Aliphatic Hydrocarbon Contents (mg/l)

\begin{tabular}{|c|c|c|c|c|c|c|c|c|c|c|}
\hline COMPONENT & Bh1 & Bh2 & Bh3 & Bh4 & R1 & W1 & W2 & W3 & W4 & W5 \\
\hline C8 & 0.000 & 0.000 & 0.000 & 0.001 & 0.000 & 0.004 & 0.000 & 0.000 & 0.000 & 0.000 \\
\hline C9 & 0.000 & 0.000 & 0.000 & 0.000 & 0.000 & 0.000 & 0.000 & 0.000 & 0.001 & 0.000 \\
\hline C10 & 0.000 & 0.010 & 0.000 & 0.000 & 0.002 & 0.000 & 0.020 & 0.000 & 0.000 & 0.000 \\
\hline C11 & 0.000 & 0.000 & 0.000 & 0.000 & 0.000 & 0.000 & 0.000 & 0.000 & 0.000 & 0.004 \\
\hline $\mathrm{C} 12$ & 0.000 & 0.000 & 0.000 & 0.000 & 0.000 & 0.000 & 0.000 & 0.100 & 0.040 & 0.000 \\
\hline $\mathrm{C} 13$ & 0.010 & 0.000 & 0.007 & 0.005 & 0.000 & 0.000 & 0.000 & 0.000 & 0.000 & 0.000 \\
\hline C14 & 0.000 & 0.000 & 0.000 & 0.000 & 0.000 & 0.000 & 0.000 & 0.000 & 0.000 & 0.000 \\
\hline $\mathrm{C} 15$ & 0.000 & 0.000 & 0.000 & 0.000 & 0.000 & 0.000 & 0.000 & 0.000 & 0.000 & 0.010 \\
\hline $\mathrm{C} 16$ & 0.000 & 0.030 & 0.000 & 0.010 & 0.040 & 0.000 & 0.000 & 0.000 & 0.000 & 0.000 \\
\hline C17 & 0.030 & 0.000 & 0.000 & 0.000 & 0.000 & 0.020 & 0.000 & 0.000 & 0.000 & 0.000 \\
\hline Pristane & 0.000 & 0.000 & 0.000 & 0.000 & 0.000 & 0.000 & 0.000 & 0.000 & 0.000 & 0.004 \\
\hline $\mathrm{C} 18$ & 0.000 & 0.000 & 0.000 & 0.000 & 0.000 & 0.000 & 0.003 & 0.000 & 0.000 & 0.000 \\
\hline Phytane & 0.000 & 0.000 & 0.000 & 0.000 & 0.000 & 0.000 & 0.000 & 0.000 & 0.008 & 0.000 \\
\hline C19 & 0.000 & 0.020 & 0.000 & 0.000 & 0.000 & 0.000 & 0.000 & 0.070 & 0.000 & 0.040 \\
\hline $\mathrm{C} 20$ & 0.041 & 0.000 & 0.000 & 0.000 & 0.000 & 0.000 & 0.000 & 0.000 & 0.000 & 0.000 \\
\hline $\mathrm{C} 21$ & 0.000 & 0.000 & 0.020 & 0.000 & 0.000 & 0.040 & 0.000 & 0.000 & 0.000 & 0.000 \\
\hline $\mathrm{C} 22$ & 0.010 & 0.010 & 0.000 & 0.020 & 0.050 & 0.000 & 0.030 & 0.000 & 0.080 & 0.000 \\
\hline $\mathrm{C} 23$ & 0.000 & 0.000 & 0.000 & 0.000 & 0.000 & 0.000 & 0.000 & 0.200 & 0.000 & 0.000 \\
\hline $\mathrm{C} 24$ & 0.020 & 0.000 & 0.000 & 0.040 & 0.000 & 0.070 & 0.004 & 0.000 & 0.000 & 0.000 \\
\hline $\mathrm{C} 25$ & 0.000 & 0.005 & 0.003 & 0.000 & 0.010 & 0.000 & 0.000 & 0.000 & 0.000 & 0.000 \\
\hline $\mathrm{C} 26$ & 0.000 & 0.000 & 0.000 & 0.000 & 0.040 & 0.000 & 0.000 & 0.100 & 0.005 & 0.010 \\
\hline $\mathrm{C} 27$ & 0.000 & 0.000 & 0.000 & 0.000 & 0.000 & 0.010 & 0.000 & 0.000 & 0.000 & 0.000 \\
\hline $\mathrm{C} 28$ & 0.000 & 0.000 & 0.000 & 0.000 & 0.000 & 0.000 & 0.000 & 0.002 & 0.000 & 0.000 \\
\hline $\mathrm{C} 29$ & 0.000 & 0.000 & 0.000 & 0.000 & 0.000 & 0.000 & 0.020 & 0.000 & 0.003 & 0.000 \\
\hline $\mathrm{C} 30$ & 0.000 & 0.000 & 0.000 & 0.000 & 0.000 & 0.000 & 0.000 & 0.000 & 0.000 & 0.000 \\
\hline C31 & 0.000 & 0.000 & 0.000 & 0.000 & 0.000 & 0.000 & 0.000 & 0.000 & 0.000 & 0.000 \\
\hline $\mathrm{C} 32$ & 0.000 & 0.000 & 0.000 & 0.000 & 0.000 & 0.000 & 0.000 & 0.000 & 0.000 & 0.000 \\
\hline C33 & 0.000 & 0.000 & 0.000 & 0.000 & 0.000 & 0.000 & 0.000 & 0.000 & 0.000 & 0.000 \\
\hline Total(mg/L) & 0.081 & 0.075 & 0.030 & 0.076 & 0.160 & 0.154 & 0.077 & 0.422 & 0.178 & 0.058 \\
\hline
\end{tabular}


Total of twenty eight (28) different aliphatic hydrocarbons were tested for across the ten (10) different samples (Bh1, Bh2, Bh3, Bh4, R1, W1, W2 W3, W4 and W5).

\section{Table 2: Polycyclic Aromatic Hydrocarbon Concentrations in Water Samples (mg/l)}

\begin{tabular}{|l|l|l|l|l|l|l|l|l|l|l|}
\hline COMPONENT & B h1 & B h2 & B h3 & B h4 & R1 & W1 & W2 & W3 & W4 & W5 \\
\hline Naphthalene & 0.000 & 0.000 & 0.000 & 0.000 & 0.000 & 0.000 & 0.000 & 0.000 & 0.000 & 0.000 \\
\hline 2-methylinaphthalene & 0.000 & 0.000 & 0.000 & 0.000 & 0.000 & 0.000 & 0.000 & 0.000 & 0.002 & 0.000 \\
\hline Acenaphthalene & 0.001 & 0.001 & 0.001 & 0.000 & 0.001 & 0.000 & 0.001 & 0.001 & 0.000 & 0.002 \\
\hline Acenaphthene & 0.000 & 0.000 & 0.002 & 0.001 & 0.000 & 0.00 & 0.001 & 0.000 & 0.001 & 0.002 \\
\hline Fluorene & 0.001 & 0.000 & 0.000 & 0.000 & 0.000 & 0.000 & 0.002 & 0.001 & 0.002 & 0.000 \\
\hline Phenanthrene & 0.000 & 0.000 & 0.000 & 0.000 & 0.001 & 0.00 & 0.000 & 0.000 & 0.000 & 0.001 \\
\hline Anthracene & 0.001 & 0.001 & 0.000 & 0.001 & 0.000 & 0.000 & 0.000 & 0.000 & 0.001 & 0.000 \\
\hline Fluoranthene & 0.000 & 0.000 & 0.001 & 0.000 & 0.000 & 0.000 & 0.000 & 0.000 & 0.000 & 0.000 \\
\hline Pyrene & 0.000 & 0.000 & 0.000 & 0.000 & 0.000 & 0.000 & 0.000 & 0.000 & 0.000 & 0.000 \\
\hline Benzo[a]anthracene & 0.000 & 0.000 & 0.000 & 0.000 & 0.000 & 0.000 & 0.000 & 0.000 & 0.000 & 0.000 \\
\hline Chrysene & 0.000 & 0.000 & 0.000 & 0.000 & 0.000 & 0.000 & 0.000 & 0.000 & 0.000 & 0.000 \\
\hline Benzo[b]fluoranthene & 0.000 & 0.000 & 0.000 & 0.000 & 0.000 & 0.000 & 0.000 & 0.000 & 0.000 & 0.000 \\
\hline Benzo[a]pyrene & 0.000 & 0.000 & 0.000 & 0.000 & 0.000 & 0.000 & 0.000 & 0.000 & 0.000 & 0.000 \\
\hline Benzo[k]fluoranthene & 0.000 & 0.000 & 0.000 & 0.000 & 0.000 & 0.000 & 0.000 & 0.000 & 0.000 & 0.000 \\
\hline Indeno[1,2,3-cd]pyrene & 0.000 & 0.000 & 0.000 & 0.000 & 0.000 & 0.000 & 0.000 & 0.000 & 0.000 & 0.000 \\
\hline Dibenzo[a,h]anthracene2 & 0.000 & 0.000 & 0.000 & 0.000 & 0.000 & 0.000 & 0.000 & 0.000 & 0.000 & 0.000 \\
\hline Benzo[g,h,I]perylene & 0.000 & 0.000 & 0.000 & 0.000 & 0.000 & 0.000 & 0.000 & 0.000 & 0.000 & 0.000 \\
\hline Total(mg/L0 & 0.003 & 0.002 & 0.004 & 0.002 & 0.002 & 0.002 & 0.004 & 0.002 & 0.007 & 0.005 \\
\hline
\end{tabular}


International Journal of Computer Applications Technology and Research

Volume 7-Issue 07, 241-254, 2018, ISSN:-2319-8656

17 different PAHs were tested for in the same sample of groundwater sin the study area. The analytical result of the samples shows the concentrations of the Aromatic components generally fall within the range $0.002-0.007 \mathrm{mg} / 1$. The total concentrations of both the Aliphatic and the Aromatic components of the hydrocarbon in the groundwater samples, the concentrations ranges from $0.034 \mathrm{mg} / \mathrm{l}$ to $0.424 \mathrm{mg} / \mathrm{l}$ are show in the table below. 
International Journal of Computer Applications Technology and Research

Volume 7-Issue 07, 241-254, 2018, ISSN:-2319-8656

Table 3: Summation of concentrations of TPH and PAH in samples

\begin{tabular}{|l|l|l|l|l|l|l|l|l|l|l|}
\hline COMPONENT & Bh1 & Bh2 & Bh3 & Bh4 & R1 & W1 & W2 & W3 & W4 & W5 \\
\hline Aliphatics HC & 0.081 & 0.075 & 0.030 & 0.076 & 0.16 & 0.154 & 0.077 & 0.422 & 0.178 & 0.058 \\
\hline PAH & 0.003 & 0.002 & 0.004 & 0.002 & 0.002 & 0.002 & 0.004 & 0.002 & 0.007 & 0.005 \\
\hline TPH(mg/L) & 0.084 & 0.072 & 0.034 & 0.078 & 0.162 & 0.156 & 0.081 & 0.424 & 0.185 & 0.063 \\
\hline
\end{tabular}

The summation of the concentrations are plotted in the bar chart shown below just to show the concentrations across different sample locations and sources.

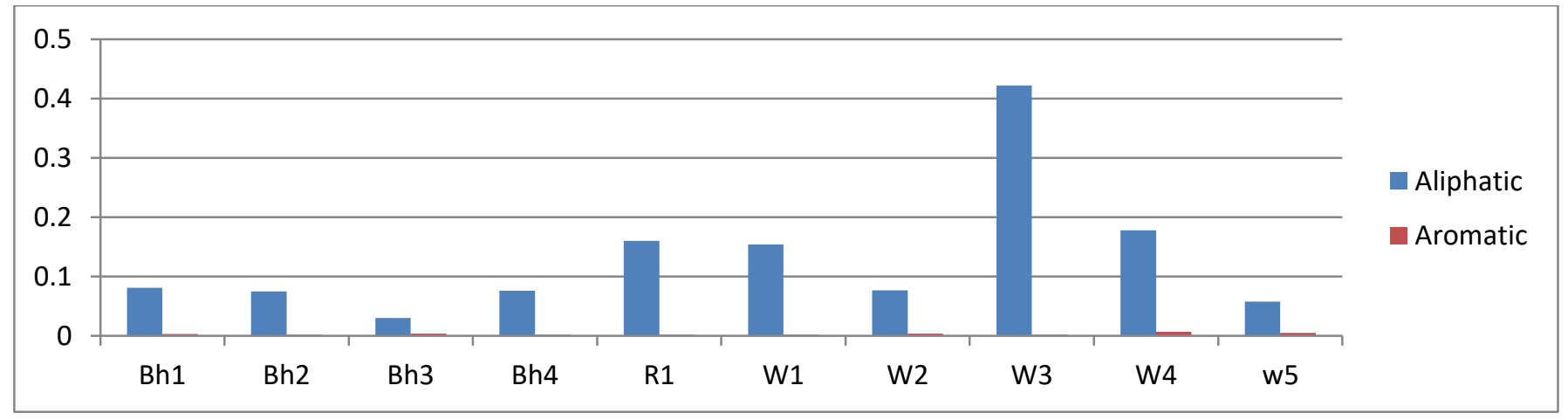

Fig 1: Aromatic and Aliphatic concentration level compared in bar graph $(\mathrm{Bh}=$ borehole, $\mathrm{W}=$ well $)$ 
The chart above shows that the aliphatic components were more in concentration than the aromatics.

The statistical mean compared with the WHO standard of $0.2 \mathrm{mg} / \mathrm{l}$ reveals that the content of the TPH in the ground water sample is within acceptable limit. T-test analysis on the mean value of hydrocarbon concentrations of groundwater against the acceptable standard as fixed by the world Health Organization (WHO) at 95\% significance level, as at the time of study reveals that oil spill in the study area has no significance effect on the groundwater quality, thus the water is suitable for domestic uses and constitute no serious health risk threat.

The aliphatic components were more in concentration than the aromatics. This describes the chemistry of the crude and the fact that the aliphatic seems to persist in groundwater more than the aromatic due to their physical properties which are responsible for the different dispersion rates of the aliphatic and aromatic components. The aromatics are more soluble in nature, this affect the rate of their transportation infiltration and dispersion (transportation). The aliphatic can easily infiltrate through formations to the groundwater due to their less solubility nature, these suggest how fast they travels through the tortious path followed by groundwater which greatly affect the concentration levels; the higher the concentrations of the aliphatic component the more $\mathrm{mg} / \mathrm{l}$ left in the environment - water (groundwater).

Only little fractions of aromatic components dissolve in water after petroleum spill in the environment, and this can be as low as only $2 \%$ [11]. Other parts are absorbed in the sediment or soil. Lighter 3 or 4 ring aromatic molecules are soluble in water, but the PAHs consisting of 5 or more aromatic rings are not soluble in water and will become associated with the sediment [4], [15]. This makes them more persistent in sediment and less available in groundwater

The rate of mobility for hydrocarbon of the same carbon bands, the rate of absorption which tend to concentrates the aromatic in the sediments, viscosity and high transportation rate of the aliphatic suggest reasons for higher level of the aliphatic component than the aromatic components in groundwater of the study area.

\section{Summary of Findings}

The analytical result of the samples shows that the concentrations of total petroleum hydrocarbon content in the water samples is generally low, the result of the aliphatic component generally fall in the range $0.03-0.422 \mathrm{mg} / 1$ while the aromatic components ranges from 0.002 $0.007 \mathrm{mg} / \mathrm{l}$. 
The analytical result shows that there is little differences in concentrations values of TPH in the samples obtained from the borehole and the well, the bore hole values ranges between $0.034-0.084 \mathrm{mg} / \mathrm{l}$ having the mean value of $0.067 \mathrm{mg} / 1$ while the samples form the Well ranges from (0.063-0.185) having the mean value of $0.1818 \mathrm{mg} / \mathrm{l}$ this little differences in value might be attributed to the result of physical, chemical, and biological effect of the natural remediating factors (biodegradation, sorption, dilution etc.) which might have occurred during the infiltration of the hydrocarbon contaminants. The average borehole depth in Jesse is estimated to be $90 \mathrm{ft}$ while the hand dug wells is $48 \mathrm{ft}$. Thus, the differences in depth between the bore-hole and hand dug well allows further microbial activities prior degradation of the hydrocarbon, dilution, sorption etc. which suggest the reason for the changes in the concentration of TPH contents. The values of the sample collected from the surface water (R1) is $(0.162)$ this can also be attributed to the effect of the flowing property of the river such as oxygenation of the water body which enhances easy decomposition of the contaminants.

However, since the study area is made up of over $70 \%$ sand, which tend to enhance the mobility and diffusion of the contaminants, the transportation of hydrocarbon contaminants from the point of the spillage to the groundwater must have undergone series of biological, chemical and physical processes that alter its composition and concentrations. Thus, these natural attenuation mechanisms of hydrocarbons are therefore considered the reason for the low concentrations of hydrocarbon in the groundwater of the study area.

This study was carried out on water samples obtained from Jesse and its environs which underlain by the Benin formation of the Niger-Delta Basin. The Result of the GC-MS analysis indicated the presence of five major PAHs; Acenaphthylene, Acenaphthene, Florene, Phenanthrene, and Anthraces and $0.00-0.002 \mathrm{mg} / \mathrm{l}$ in all the samples from different locations within the study area. Generally the TPH mean ranges from $0.001-0.015 \mathrm{mg} / \mathrm{l}$ which is within the acceptable limit of 0.2 as recommended by WHO in 2012, this inferred that the Total Petroleum Hydrocarbon concentrations identified in all the samples are very low and as such can pose less threat to the health of the individuals living within the study area

The study however concludes that:

- $\quad$ The level of hydrocarbon contaminants in the study area is within acceptable limits

- The petroleum activities in the study area has no significant effect on the groundwater resource 
- Groundwater contaminations pose no health risk due to the consumption of the ground water in the study area

This research work centered on identifying the levels of concentration of hydrocarbons in groundwater in the study area with a view to determine the associated risks. It follows however that this research has succeeded in providing vital information as summarized below.

- It reveals the levels of concentration of hydrocarbons in groundwater in Jesse and environs, and the potentials for natural attenuation in the environment.

- $\quad$ The study also tried to bridge the gap in knowledge on the fate of the hydrocarbon spillage and its effect on the groundwater in the study area.

- $\quad$ The study also revealed that the groundwater is safe for domestic usage as long as the trend remained monitored. Monitoring therefore will serve for the protection of the groundwater supply in the study area.

Thus, this study will be of relevance to a wide range of individuals and organizations including; Students and researchers for further studies, government and policy makers and the general public especially the inhabitants of the study area.

\section{References}

[1] Abbey, E., Abrams, C. \& Athony, N. (2003). Effect of crude oil spillage on soil and microbiological properties of a tropical rainforest: Institute of pollution studies and biological science Imo state University, Owerri. $3^{\text {rd }}$ ed, Pacific Publication : 122-125

[2] Akpofure, A.E., Efere, L.M \& Wei, A.P. (2006). The adverse effect of crude oil spill in Niger Delta. Online Internet web report at http//: www. waado.org/environment.(accessed on $09-01-17$

[3] Amukali. O. (2012). Effects of gas flaring and oil spillage on water quality for domestic use in Okpai and Beneku, Delta State, Nigeria. Unpublished M. Sc. Thesis, Department of Geography, University of Maiduguri 48p

[4] Cerniglia, C. E. (1992). Biodegradation of polycyclic aromatic hydrocarbons. Biodegradation 3,351-368.

[5] Chiyem, F.I., Ohwoghere-Asuma, O. \& Nwankwoala, H.O.( 2014). 2D Electrical Resistivity Imaging of Unsaturated and Saturated Zones for crude oil spillage at Agbarha in Ughelli area of Delta State, Nigeria: New York Science Journal, 7(12),127-150

[ 6] Dami A., Ayuba HK \& Amukali O. (2012). Effects of gas flaring and oil spillage on rainwater collected for drinking in Okpai and Beneku, Delta State, Nigeria: Global Journal of Human Social Sciences 12(13),35-45

[7] Dami, A., Ayuba H. K \& Amukali, O. (2013). Ground water pollution in Okpai and Beneku, Ndokwa east local government area, delta state, Nigeria: Journal of Environmental Research and Management 4(1),171179.

[8] Delille, D., \& Bassères, A. (1998). Influence of daylight on potential biodegradation of diesel and crude oil in Antarctic seawater. Marine environmental research 45(3), 249-258.

[19] Knap, A. H. (1982). Experimental studies to determine the fate of petroleum hydrocarbons from 
International Journal of Computer Applications Technology and Research Volume 7-Issue 07, 241-254, 2018, ISSN:-2319-8656

refinery effluent on an estuarine system: Environmental Science and Technology 16,1-4.

[10] Lichtenthaler, R. G. \& Haag, W. R. (1989). Photooxidation of probe compounds sensitized by crude oils in toluene and as an oil film on water: Environmental Science and Technology, 23, 39-45.

[[11] Nicodem, D. E. \& Fernandes., M. C. Z. (1997). Photochemical processes and the environmental impact of petroleum spills. Biogeochemistry.2,121-138.

[12] Nwankwo CN \& Ogagarue D. O. (2011). Effects of gas glaring on surface and ground waters in Delta State, Nigeria. In Journal of Geology and Mining Research. 3(5), 131-136.

[13] Nwilo, C.P. \& Badejo, T.O. (2008). Management of oil dispersal along the Nigerian coastal areas:

Department of Survey \& Geoinformatics, University of Lagos, Nigeria. www.oceandocs. org/handle/1834/267

[14] Okolie, Ec; Osemeikhian, Jea \& Ujuanbi, O. (2007). Determination of formation strata and groundwater potential in Sapele Metropolis and Environ: Journal of Applied Science and Environmental Management 11(2), $181-186$

[15] Ordinioha B. \& Seiyefa B. (2013). The human health implications of crude oil spills in the Niger Delta, Nigeria: an interpretation of published studies: Nigerian Medical Journal, 54:10.

[16] Shor, L. M. \& Kosson,. D. S (2004). Combined effects of contaminant desorption and toxicity on risk from PAH contaminated sediments. Risk Analysis,5(2),1109-1120.

[17] United Nation Environment Programme (UNEP 2006). Report on Ogoni-land. Community research and development journal 6(2)101120. 